\title{
UNDERSTANDING THE CAUSES AND DYNAMICS OF CONFLICTS IN GHANA: INSIGHTS FROM BAWKU TRADITIONAL AREA
}

\section{Lawrence Opoku Agyeman}

Rural Development College, Kwaso, Post Office Box 2, Ejisu-Ashanti, Ghana Lawopoku47@Gmail.Com, 0548997718/0242161108

DOI//http://dx.doi.org/10.4314/gjds.v18i2.5

\section{ABSTRACT}

A Conflict can be resolved when there is an adequate understanding of its causes. The objective of this study is to contribute to the understanding of the contributory factors of the Bawku chieftaincy conflict as a case study and explore the lasting solutions to the conflict which contributes to the political, cultural, and socio-economic development. The study surveyed 200 householders using systematic and snow-balling in five spatial locations in the Bawku Traditional Area. Subsequently, face-to-face interviews were conducted with the Traditional Authorities, the Police, and the Belim-Wusa Development Agency to verify the claims made in the survey and to obtain further insights into the conflict. The responses obtained from the interviews were analyzed for patterns and themes and used as narratives in the work. The geographical location and socio-economic activities such as population growth, farming, and poverty have made the Bawku Traditional Area more prone to persistent conflicts. Again, other contributory factors included; political interference, freedom from fear, a proliferation of small arms, and inadequate access to social services. The empirical findings support the proposition that political interventions sowed the seed of the Bawku conflict. The study recommended that the National Peace Council should organize a workshop to educate the political parties on the need to stay away from chieftaincy matters.

Keywords; Conflicts, Violence, Chieftaincy, Bawku Traditional Area, Ghana 


\section{INTRODUCTION}

Conflict is defined as a struggle between two or more people over value, status, power, and resources come unsurprisingly as a consequence of human interactions in which the aims of the parties are not only to gain the desired outcomes but also to get rid of their rivals (Coser, 1956 as cited in Tona \& Anamzoya, 2016). Conflicts have been known to be associated with several countries across the globe. African countries have gotten their fair share mostly in Angola, Congo, Egypt, Liberia, Morocco, Nigeria, Sierra Leone, and Uganda (Olaosebikan, 2010).

Ghana has been described worldwide as the center of peace in Sub-Saharan Africa. However, various examples show that violent conflicts occur from time to time. The most common example of these conflicts is the Bawku chieftaincy conflict. For instance, there were skirmishes in 2000, 2001, 2007, 2008, and 2009. The situation has received several interventions from the Ghana government and other nonstate actors. For instance, the Nairobi Peace Initiative (NPI) has organized several reconciliation workshops for the two feuding parties. Yet, the Bawku conflict remains unresolved. With this, the central research question is this; what factors and circumstances are accountable for violent conflicts in the Bawku Traditional Area (BTA)?

In the pursuit of this, the objective of this study is to contribute to the understanding of the contributory factors and explore the lasting solutions to the conflict which contributes to political, cultural, and socio-economic development. This study argues that political interventions sowed the seed of the Bawku conflict. This study is organized into three sections. Section one provides the background and reviews related literature on conflicts and development. Section two explores the methodological perspectives of the study. Section three assembles and analyses the responses of the respondents on the Bawku conflict. This section concludes the responses of the respondents on the Bawku conflict. It also explores solutions to the research problem to facilitate socio-economic development in Bawku Traditional Area.

\section{LITERATURE REVIEW}

Conflict is ever-present in human society. It occurs between individuals, groups, nations, and organizations. Conflict is defined as opposing views involving competition over the limited resources that could result in the death or destruction 
of properties. Galtung (1996) identified incompatibility, clash of goals, or values as the potential drivers of conflicts. Sandole (2010) also conceptualizes conflict as a dynamic process characterized by the initiation, escalation, controlling, and transformation. The difference between Galtung's (1996) and Sandole's (2010) definition is that; Galtung conceived conflict as a cause while Sandole perceived conflict as a process. The conventional wisdom holds that conflicts are bad or negative. Conflicts are not necessarily negative; it gives us insight into the issue that needs to be handled within groups.

Conflicts start as disputes and are beneficial if resolved early. When a conflict is resolved, it does not lead to violent conflicts, when it escalates it becomes a violent conflict. At this stage, parties make efforts to reach an agreement. When the parties decide to resolve the conflict, then the parties are in the hurting stalemate stage (Zartman, 2000).

The study explores the Bawku conflict through the theoretical lens of protracted social conflict theory. The protracted conflict theory was postulated by Edward Azar in 1990 and reinforced by Coleman (2000). The theory is defined as flare-up conflicts by groups for such basic needs as security, identity, recognition, power, and access to resources (Coleman, 2000).

According to Azar (1990), security, freedom from fear, the recognition of one's identity is the prime motivator of social conflicts. These human needs are provided by the state through the provision of public goods. Protracted conflicts are often intense, deadlocked, persistent, chronic, intricate, and the effects are often pervasive, thus affecting all aspects of development could occur if these needs are unmet or unsatisfied. Therefore, conflict resolution and peace-building must address these non-hierarchical, non-negotiable needs.

The Bawku chieftaincy conflict is a struggle between Kusasis and Mamprusis over the occupancy of the Bawku throne as Bawkunaba (Awedoba, 2009; Longi, 2014). Available literature suggests that when the slave trade was still flourishing in northern Ghana, Na Atabia, the Nayiri of Mamprusi who lived in Nalerigu sent his son Prince Ali to establish a police post at Bawku, Sinnebaga, Binduri, Teshi, Tanga, and Worikambo to strengthen the trade route between Tenkudugu and Nalerigu (Syme, 1932; Opoku-Afari, 1958; Longi, 2014). With the support of the White Colonial District Commissioner for Bawku, Nayiri appointed Mamprusi princes as chiefs in those places which were predominantly Kusasi settlements (Syme, 1932). 
In 1957, the Mamprusi Bawkunaba died and this created a vacancy for the Bawku skin. Yiremia Mamprusi was appointed on 6th June 1957 in the face of opposition from the other princes. Disagreement and misunderstanding broke out at Nayiri's palace when Yeremiah was selected. The disappointed Mamprusi princes protested against the decision. Amid antagonism, Abugrago Azoka, a descendant of a Kusasi tengdana was selected and installed as Bawkunaba (Longi, 2014). The situation resulted in ethnic clashes between the Mamprusi and Kusasi hence marking the beginning of the Bawku chieftaincy conflict (Opoku-Afari, 1958).

Conflict management mechanisms in Ghana include the use of security agencies, courts system, and commission of inquiry. There are also Regional and District Security Committees appointed by the government to maintain peace in their jurisdictions (Awedoba, 2009). The constitution also allows the government to use Executive or Legislative Instruments, Acts, or Decrees to restrict the movement of people through the imposition of curfew in the conflict area. The constitution empowers the government to appoint a commission of inquiry into any matter of public interest. It is stipulated in article 279 of the constitution that the commission of inquiry shall have the powers, rights, and privileges of the High Court or a Justice of the High Court at a trial. Article 280 sub-section (2) states that the findings of commissions of inquiry be deemed to be the judgment of the High Court. Some of the commission's seldom found solutions to the conflict and some never came out with any report.

However, it is in the interest of the government to accept and implement the recommendations of the committee. The findings of commissions of inquiry have not been effective in resolving conflicts in Ghana. This can be attributed to the unfamiliarity of customary laws of the various court officials and committee members. The National Peace Council was established in the year 2006 as the center for resolving conflicts in Ghana. It had its legal mandate in 2011 under Act 818 of Parliament of Ghana. This act empowers the NPC to tailor interventions for conflict management, prevention, and transformation to achieve sustainable peace throughout the country. It is also expected to develop a conflict management framework to offer indigenous approaches to resolve conflicts.

\section{METHODOLOGY}

This section explores the logical ways of answering the research problem as it is essential to achieve the reliability and validity of the findings. The chapter details 
the design adopted for the study and explains the techniques and the methods used to select the respondents, and further discusses the tools used to collect both quantitative and qualitative data as well as data analysis techniques.

The philosophical assumptions are the general world view that guides an inquiry or shape the direction of the research process. The philosophical assumptions provide background information about the phenomena being measured. It constitutes the frame within which the research findings can be interpreted. Creswell (2009) suggested that in explaining one's philosophical assumption; the ontological and epistemological position should be defined. Regarding this, the study is based on the ontological position that reality is shaped by both the researcher and the respondent. It also adopted a mixed-method approach involving qualitative and quantitative data. This epistemological and ontological position influences the collection and analysis of the field data. However, our personal beliefs did not in any way influence the direction of the research process.

The study adopted a case study research design to explore the Bawku chieftaincy conflict. This is appropriate for the study because this study intends to acquire information that is useful for understanding the dynamics and depth of chieftaincy conflicts in Ghana. A case study is suitable when there is the availability of a case that merits an investigation. Yin (1984:23) defines a case study "as an empirical inquiry that investigates a contemporary phenomenon within its real-life context, when the boundaries between phenomenon and context are not evident and in which multiple sources of evidence are used". A case study facilitates the understanding of the opinions and attitudes of the respondents of the Bawku Traditional Area (BTA).

The research process begins with a reconnaissance survey to establish rapport with key stakeholders for the subsequent data collection. Following this, a visit was made to the Bawku Naba's palace, Bawku Inter-Ethnic Peace Committee (BIEPC), Kusaug Traditional Council (KTC), and Belim Wusa Development Agency (BWDA). This was done to collect any initial documents on the conflict and also ask for permission from the Bawku Naba and the Tendanas to conduct the survey.

On the 10th of January 2020, a prior notice was given to the BIEPC, KTC, and BWDA that they have been selected to provide the needed information to achieve the objectivity of this study. On the next day, I was introduced to the Naba Thomas Abilla, the chief of the Wande community who then introduced me to the Tendanas or the landowners in Bawku. The Tendanas took me to the Bawku Naba's palace. At the palace, my submission was presented through the Council of Elders to 
the Bawku Naba. On the second day, I interacted with the BWDA and KTC on the triggers of the Bawku conflict. Through the reconnaissance survey, a visit was also made to the District Planning Officer (DPO) to collect secondary data on the proportion and distribution of each ethnic group in the area. The data gathered was used to estimate the sample size for each ethnic group. It was discovered through the reconnaissance survey that the Kusasis and the Mamprusis which are the predominant ethnic groups lived in different spatial locations.

To achieve the reliability of the study findings, a three-day training exercise was organized to train five enumerators on data collection methods and techniques. The training was facilitated by a friend who holds a Ph.D. in Development Studies and is a lecturer at Kwame Nkrumah University of Science and Technology, Kumasi (KNUST). The five enumerators were students at Rural Development College, Kwaso but were natives of Bawku. The training took place on 3rd December 2019. This training aimed to prepare the pilot survey instruments. The training covered the following areas; discussions about ethics in research, how to introduce oneself in the field, and how to administer the questionnaire. The questionnaires were revised by the Director of Postgraduate Programs at the Department of Planning, Kwame Nkrumah University of Science and Technology (KNUST).

The questionnaires were pre-tested immediately after the training to assess the feasibility of the research questions. This was also done to expose the five enumerators to the primary data collection exercise and to test the sufficiency of data collection instruments used and how the respondents understood the research questions. The pilot survey took place from 5 th to 12 th January 2020 at Bawku Municipality. In all 30 householders were selected for the pilot survey. The pilot survey revealed that the questionnaires were feasible.

The process of gathering, and analyzing data started with the determination of the sample size for the quantitative survey. Literature shows that a sample could be used as it is not necessary to study everything to form an opinion about a phenomenon (as cited in Neuman, 2014). The use of a sample in research implies that the proportion used for the study is not significantly different from the population in Bawku Traditional Area (BTA). Israel (2003) as cited in Nanor et al., (2018) provided the formula to calculate the sample size as $\mathrm{n}=\mathrm{N} / 1+\mathrm{N}$ (e) 2 with the confidence level of $95 \%$. Where $n$ is the sample size, $\mathrm{N}$ is the sample frame, e is the Error margin and 1 is the constant. The householders (sample frame) in BTA are given as 14,325 (Ghana Statistical Service, 2012). The above-stated formula was used to arrive at a sample size of 389 . 
However, the criterion for determining a sufficient sample size in a case study research is saturation (Gentles et al., 2015). In the survey, the study reached informational redundancy after surveying 200 household heads. This gave a strong justification to reduce the sample size to 200 householders. Before the data collection exercise, the BTA was divided into five subgroups based on the spatial distribution of ethnic groups. The rationale was to maintain a delicate balance in the selection of householders. The proportion of each sub-group was proportionally distributed as follows (see Table1).

Table 1: Number of Households Surveyed in Bawku Traditional Area

\begin{tabular}{|l|l|l|}
\hline Sub-Groups & Number of households & $\begin{array}{l}\text { Number of Households } \\
\text { Surveyed }\end{array}$ \\
\hline Kusasis & 6,755 & 90 \\
\hline Mamprusis & 3,753 & 50 \\
\hline Mossi & 2,252 & 30 \\
\hline Hausa & 1,502 & 20 \\
\hline $\begin{array}{l}\text { Busanga, Frafra, Kasena, } \\
\text { and Dagombas }\end{array}$ & 750 & 10 \\
\hline Total & 15,012 & 200 \\
\hline
\end{tabular}

Source, Author's Construct, 2019

The primary data collection process was divided into two phases, namely, survey and structured interviews. In the first phase, a survey was carried out to provide insight into what to specifically ask during the detailed interview scheduled and further identify key informants for the structured interviews. Questionnaires were administered to household heads in the area.

The second part of the primary data collection process involved face-face interviews. From the survey, the householders who were knowledgeable about the conflict were selected as key informants for the face-to-face interviews to verify the claims made in the survey and to obtain further insights into the conflict.

The process of selecting the respondents was divided into two stages. In the first stages, the BTA was stratified into five subgroups based on the distribution of ethnic groups. The systematic sampling was used to select every Kth householders for the survey until the estimated sample size was secured. Kothari (2004) defined systematic sampling as a special type of sampling in which the selection of respondents is based on randomization. Bluman (2004) asserted the researcher 
obtain systematic samples by selecting every Kth unit. Newman (2014) argued that in systematic sampling the respondents are selected using the quasi-random selection procedures. The random methods were used to pick a starting point and continue until the estimated sample size for the group was exhausted. Systematic sampling was used to select the Kusasis and the Mamprusis as they were not mixed up. Because the other ethnic groups were mixed up, it was not possible to use systematic sampling; therefore snow-balling was used to select the Hausas, the Mossis, Busangas, Frafras, Kasena, and Dagombas. However, because there was no sampling frame for householders, households were used as a proxy for household heads.

In the second stage, a purposive sampling technique was used to select the institutions within the BTA that have adequate information on the Bawku conflict. The result of the purposive sampling procedure was the selection of the traditional authorities, the police, the Belim Wusa Development Agency, and the Bawku InterEthnic Peace Committee. The intention was to obtained professional insights to answer the research questions.

Units of analysis are the observable units that must be measured to get a deeper insight into the conflict situations (Kumekpor, 2002). The unit of analysis was divided into three phases, namely, the geographical units, individual units, and institutional units. The geographical unit was the Bawku Municipality. The individual units were the household heads in Bawku Municipality. The institutional units were the Traditional Authorities, the Police, Bawku Inter-Ethnic Peace Committee, and Belim Wusa Development Agency.

The data gathered from the survey were edited, coded, and entered into the Statistical Package for Social Sciences (SPSS) version 20 and Microsoft Excel for analysis. The data generated from the SPSS and Microsoft Excel were analyzed using descriptive statistics. The SPSS was used to generate tables, frequencies, and percentages. On the other hand, Microsoft Excel was used to generate charts and figures. The qualitative data were recorded, transcribed, and examined severally to identify common themes and patterns and used as narratives in the study.

The sensitivity of the topic of this nature called for ethical consideration. The study was conducted with strict adherence to the principles of confidentiality and voluntary participation. The safety of enumerators and respondents was guided by the direction of the research. To guarantee the safety of the respondents, an 
introductory letter was obtained from the Department of Planning (KNUST) to ensure respondents that the information provided will be treated confidentially.

The household heads and the key informants were informed about the principles of confidentiality and anonymity. No names or addresses appeared on the questionnaires and the interview guides. The five enumerators were trained and were asked to obtain the permission of respondents to record interviews. The qualitative data that were recorded using self-phones were kept on the desktop and destroyed after transcription. The analysis of the data was done without the household identities such as names and addresses were protected and not used in the analyses. To protect the identity of the householders, the word respondents were used throughout the analysis of the field data.

\section{FINDINGS AND DISCUSSIONS}

This section is organized into distinct themes explored in the process of transcribing the field data. The themes identified included; political interventions, freedom from fear, the proliferation of small arms, and inadequate access to social services. However, the section begins with a profile of the Bawku Traditional Area (BTA) to provide the baseline data and also establishes the context for understanding the dynamics of the Bawku conflict. The features of BTA that were relevant to the research included the location, population size, and other development indicators.

\section{Locating Bawku Traditional Area}

The BTA is located in the Upper East Region. It is boarded to the north by Burkina Faso, to the east by the Republic of Togo, to the west by the Nabdam District, and to the south by the Mamprusis East District in the North- East Region of Ghana (Ghana Statistical Service, 2012). The BTA is divided into two by the White Volta. The Eastern half is called Agolle and the Western half is known as Atoende (Awedoba, 2009).

The largest and most important town in the area is Bawku which is also the administrative capital of Bawku East district. Bawku was upgraded in 1989 by the Legislative Instrument, L.I. 1439 as the district capital of the Bawku East District. Bawku is situated to the North of the Agolle District on the route between the Gambaga and Wagadugu. Bawku being located in the Upper East Region share poverty characteristics of the three northern regions that are Northern, Upper East, 
and Upper West, which are the poorest regions in the country (Ghana Statistical Service, 2015). Table 2 shows the estimated number of poor persons in the BTA.

The Bawku West district placed 9th on the poverty headcount in Ghana with a percentage score of $68.1 \%$ and Garu Tempane district recorded the highest number of poor persons $(70,087)$ in Ghana. Similarly, the Bawku Municipality placed 31st position on the poverty headcount with a total of 40,823 poor persons (Ghana Statistical Service, 2015). This implies that the majority of householders (50\%) in the area are poor. This suggests that the BTA being located in the poverty zone makes it more prone to persistent conflicts. This validates the assertions of Smith's (2004) studies that when poverty increases, violent conflicts become likely and vice versa.

Table 2: Estimated Numbers of Poor Persons in the Bawku Traditional Area

\begin{tabular}{|l|l|l|l|l|}
\hline Districts & $\begin{array}{l}\text { Household } \\
\text { Population }\end{array}$ & $\begin{array}{l}\text { Estimated } \\
\text { number of } \\
\text { poor persons }\end{array}$ & $\begin{array}{l}\text { Percentage } \\
\text { of poor per- } \\
\text { sons }\end{array}$ & Rank \\
\hline Bawku West & 93,028 & 63,315 & 68.1 & 9 \\
\hline Garu-Tempane & 128,623 & 70,087 & 55 & 5 \\
\hline Bawku Municipal & 97,221 & 40,823 & 42 & 31 \\
\hline Binduri & 60,878 & 26,360 & 43 & 85 \\
\hline Pusiga & 57,080 & 24,699 & 43 & 99 \\
\hline
\end{tabular}

Adapted from Ghana Statistical Service, 2015

\section{Population Growth}

Ayih (2003) attributed conflicts in the Middle Belt to population growth. Francis (2006) argued that population growth breeds land scarcity and creates competition over access to social services that fuel conflicts. The empirical data (see table 3 ) show that the Bawku Municipality has added a total of 15,719 to its population. This suggests that the current population growth rate of $1.5 \%$ has created competition over farmlands and access to social services that have fueled conflicts in the area. 
Table 3: Projected Population of Bawku Municipality from 2017-2020

\begin{tabular}{|l|l|}
\hline Year & Projected population \\
\hline 2017 & 114,257 \\
\hline 2018 & 116,912 \\
\hline 2019 & 119,590 \\
\hline 2020 & 122,335 \\
\hline
\end{tabular}

Source: Bawku Municipal Assembly, 2017

\section{Characteristics of respondents}

Marriage is one of the most cherished institutions in Ghana. It is the indicator for measuring social responsibility and trust. The empirical data show that (see figure 1) $31 \%$ of the householders are married whiles $48 \%$ are single. It further shows that $13 \%$ are divorced whiles $8 \%$ are widowed. This explains the fact that most of those who are involved in the conflict are single. This validates the assertions of Boateng's (2016) studies that the single lacked commitment to their family which makes them more prone to conflicts. 


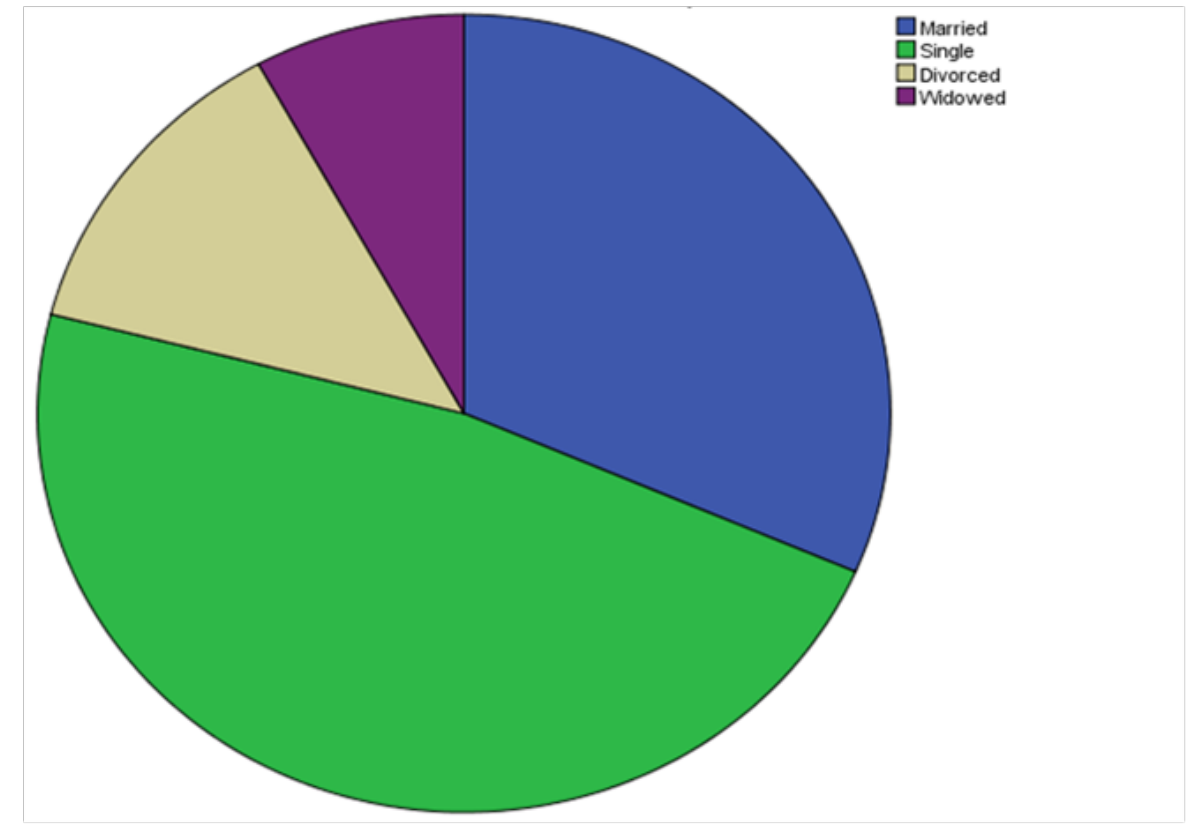

Figure 1: Marital Status of Respondents

Source, Field data, 2020 
Occupation refers to the type of work a person established to earn a living. The empirical data from the field (see table 4) shows that about $40 \%$ of the householders were farmers with $23 \%$ involved in handicraft, $5 \%$ artisan, $26 \%$ traders, and $7 \%$ public servants. This explains that most of the people who are involved in the conflict were farmers. This affirms Boateng's (2016) studies that in the rainy season conflicts increase among farmers intending to get access to fertile lands.

Table 4: Occupational Status of Respondents

\begin{tabular}{|l|l|l|}
\hline Occupational Status & Frequency & Percent (\%) \\
\hline Farming & 80 & 40.0 \\
\hline Handicraft & 46 & 23.0 \\
\hline Artisan & 10 & 5.0 \\
\hline Trading & 51 & 26.0 \\
\hline Public servant & 13 & 7.0 \\
\hline Total & 200 & 100 \\
\hline
\end{tabular}

Source, Field data, 2020

\section{THE TRIGGERS OF THE BAWKU CHIEFTAINCY CONFLICT}

Conflicts can be resolved when there is an adequate understanding of their causes. Literature shows that factors such as the power struggle and control over resources can drive conflicts (Noagah, 2013). Smith (2004) has noted that violent conflict is possible as soon as weapons are available. However, the empirical data (see figure 2) shows that the Bawku conflict was mainly caused by political interventions, the proliferation of small arms, and freedom from fear, and inadequate access to social services. These assertions were further explored in an interview and the responses obtained are discussed and analyzed in the subsequent sections. 


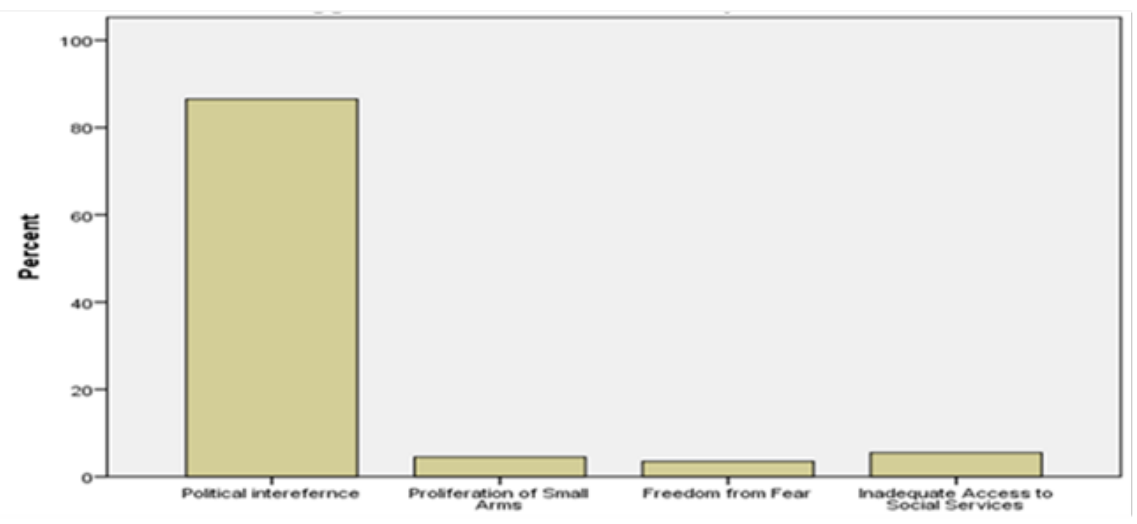

Figure 2: Triggers of the Bawku Chieftaincy Conflict

Source, Field data, 2020

\section{Political Intervention}

Literature underscores the importance of peace in sustainable development discourse (Tona \& Anamzoya, 2016). However, empirical data suggests that peace in BTA is jeopardized through political interventions. As shown in figure $2,87 \%$ of the householders attributed the Bawku conflict to political interventions. The findings show that (see table 5) the then president of Ghana passed the restoration of Chief's Act, 1959 to install Abugrago Azoka I as Bawku Naba. In 1966, the National Liberation Council (NLC) government used the NLC Decree 112 to disqualify the late Abugrago Azoka I as Bawku Naba. The late Alhaji Adam Azangbego became the beneficiary in this regard. The Provisional National Defence Council decreed the PNDCL 75 to reinstate the late Abugrago Azoka I to his formal position as Bawku Naba. Following his death in 1983 his son, Aninchema Abugrago Azoka was installed as the Bawkunaba. 
Table 5: Legislations and their Implications on Bawku Conflict

\begin{tabular}{|l|l|}
\hline Legislations & Implications on the Bawku conflict \\
\hline Restoration of Chief's Act, 1959 & $\begin{array}{l}\text { It allows Nkrumah to install the first Kusasi } \\
\text { chief }\end{array}$ \\
\hline NLC Decree 112,1966 & $\begin{array}{l}\text { It disqualified the Kusasi chief and reinstat- } \\
\text { ed the Mamprusi chief }\end{array}$ \\
\hline PNDCL 75, 1983 & $\begin{array}{l}\text { Remove the Mamprusi chief and reinstated } \\
\text { the Kusasi chief }\end{array}$ \\
\hline
\end{tabular}

Source, Field data, 2020

Similarly, when Ghana went back into party politics in 1992 the National Democratic Congress (NDC) and New Patriotic Party (NPP) intrusions in the conflict also emerged. During this period, the conflict did not stay around chieftaincy, but it went into party politics. The Kusasis find comfort whenever NDC comes into power. The Mamprusis also maintained their relationship with the Dankwa Busia tradition that is today's NPP. All the other tribes such as Bisa, Moshie, Busanga, Frafra, Kasena, and Dagomba that were supporting NPP were identified as sympathizers with Mamprusis.

Besides, all the other minority tribes that were supporting NDC were identified as sympathizers with the Kusasis. Consequently, the dynamics of the conflict have changed into party politics. Hence, the current incidents of the conflict occur during general elections or after elections results have been declared. According to the officeholder,

"When Kuffour came into power in 2000, Mamprusis thought that being a member of the Dankwa Busia tradition, he would do something to reverse the (PDNCL) 75 (Restoration of Chiefs Act). The Mamprusis decided to do their worse in 2000, $2001,2007 a n d 2008$ to force the then government to do something in their favor. Unfortunately, Kuffour did not take action of what its sympathizers wanted him to do".

\section{The proliferation of Small Arms}

As Smith, (2004) has noted that the availability of small arms is the major factor sustaining violent conflicts in African countries. The empirical data (see figure 2) shows that nine householders constituting $4.5 \%$ attributed the causes of the conflict to a proliferation of small arms by both parties. In an interview, one of the 
respondents narrated that, "In the wake of the conflict, you will hear a gunshot all over."Just recently, I heard a gunshot which since I was born, I have never heard such a sound before".

It was difficult to ascertain how these guns were distributed to both parties. The weapons were kept under a grave and a deep well near their houses. The respondents did not disclose the sources of the weapons. When questioned, the source of the weapons? One of the respondents told me that, "do you think I am a fool to answer this question".

\section{Freedom from Fear}

Azar, (1990) asserted that freedom from fear could trigger conflicts. Agyeman, (2008) argued that when a group begins to fear for their safety, they opt for measures to protect that safety, and that could lead to violence. In the case of BTA seven householders representing 3.5\% alluded to fear and mistrust as a key driver of violence in the BTA. Confirming this in an interview, one of the respondents narrated that,

"Rawlings has been our defender for so many years, now that he is going what would be our faith, so when Rawlings was exiting power in 2000 there was a fear from the Kusasis side that the Bawku skin would be taken back to the Mamprusis. The opposite side had a hope that if there was going to be a change of government, then they stand the chance of taken back the Bawku skin. In December 2000 when there was a delay in the announcement of the electoral results, it resulted in gun sharing in Bawku".

Another respondent narrated that, "we were afraid because we thought that Kuffour being a member of Dankwa Busia tradition will do something to reverse PNDCL 75. Unfortunately, Kuffour did not take action of what its sympathizers wanted him to do".

\section{Inadequate Access to Social Services}

Access to social services is essential to human welfare (Chambers, 2004). Azar (1990) argued that under the condition of unfulfilled human needs perceived threat to peace or security is likely to occur. The empirical findings (see figure 2) show that 11 household heads representing $5 \%$ identified inadequate access to social services as 
the main source of violence in the BTA. Confirming this in an interview, one of the respondents narrated that,

"The conflict normally starts on the market day whenever the Mamprusis tried to prevent the Kusasis from getting access to the animals market. The 2007 incidence was triggered by a fight between two cow sellers over access to the animals market in the Bawku central".

\section{Application of the Protracted Conflict Theory to the Findings}

Literature shows that farming engaged about $60.9 \%$ of households (GSS, 2012). It is mainly of the subsistence type where cereals, legumes, and vegetables are grown for home consumption and a little for the market. The data from the field revealed that about $40 \%$ of the householders were farmers with $23 \%$ involved in handicraft, $5 \%$ artisan, $26 \%$ traders, and $7 \%$ public servants.

In the wake of the conflict farmers engaged in the production of tomatoes and onions suffer heavy losses. Farmers were forced to abandon their crops because of the fear of being attacked and killed. Besides, the majority of householders (see table 2 ) in the area are poor. This calls for government and other non-governmental organizations to established income generation activities in the area. The empirical data show that there are eight dams located in the following communities: KukaYakin, Tambaligu, Arizim, Zabgu, Kpalwega, Lalsa, Gbegu, and Abuss. There are some communities located along with the offshoot of the White Volta mainly Bador, Gentiga Number one and two, Tampizua, and Mognori. However, if these dams are revamped, farmers can do better as dry season farming and this will help to reduced poverty in the area. Moreover, if a one district one dam project is materialized in the area farmers can do better as dry season farmers and could help farmers satisfy their basic needs.

\section{CONCLUSIONS AND RECOMMENDATIONS}

The geographical location and socio-economic activities such as population growth, farming, and poverty have made the Bawku Traditional Area more prone to persistent conflicts. Again, other contributory factors included; political interference, freedom from fear, the proliferation of small arms, and inadequate access to social services. The dynamics of the conflict have changed from chieftaincy to party politics and other socio-economic issues. The empirical data 
support the proposition that political interventions sowed the seed of the Bawku conflict. Future research should explore the implications of the Bawku conflict on development in BTA.

Based on the findings, the study recommended the National Peace Council should organize a workshop to educate the political parties on the need to stay away from chieftaincy matters. This could reduce socio-political tensions and improves the socio-economic wellbeing of the populace in BTA. Besides, the Bawku Municipality and other stakeholders should address issues related to poverty, population growth, and inadequate access to social services in the BTA. The Government of Ghana through the Ghana Police Service should use social marketing strategy to reclaim weapons from the populace in the BTA. This will make both Kusasis and the Mamprusis less prone to violent conflict.

\section{REFERENCES}

Agyeman, D. K. (2008). Managing diversity and ethnic conflicts. Ghana Governance in the Fourth Republic, 77-96. Accra, Ghana: Digibooks Ghana Limited.

Awedoba, A. K. (2009). An Ethnographic Study of Northern Ghanaian Conflicts: $\quad$ Towards a Sustainable Peace: Key Aspects of Past, Present and Impending Conflicts in Northern Ghana and the Mechanisms for Their Address (No. 3). African Books Collective. Accra, Sub-Saharan Publishers.

Ayih, S. O. (2003). Nasarawa State: Past and present. Nigeria. Abuja, Nigeria. Umbrella

Books. Retrieved from www.academia.edu on $10^{\text {thMay,2019. }}$

Azar, E. E. (1990). The management of protracted social conflicts: theory and cases. Dartmouth Publishing Company.

Azar, E.E. (1991). 'The Analysis and Management of Protracted Conflict': Alders hot: Dartmouth Bader.

Bawku Municipal Assembly. (2017). Medium term development plan (20182021). Ministry of Local Government and Rural Development, Accra, Ghana. Retrieved from http://bawkumunicipal.ghanadistrict.gov. gh on 2nd May, 2020.

Bluman, A.G., (2014). Elementary Statistics, A step by Step Approach (11th edition). New York, McGraw Hill Companies. 
Boateng, J. O. (2016). An analysis of herder-farmer conflicts in the AsanteAkim North District of Ghana (Doctoral dissertation). A thesis submitted to the Department of Planning, Kwame Nkrumah University of Science and Technology, Kumasi in partial fulfillment of the requirements for the degree of Master ofScience in Development Policy and Planning. Retrieved from http://ir.knust. edu.gh/handle/123456789/94 69 on $13^{\text {th March, } 2019 .}$

Chambers, R. (2004). Ideas for Development: Reflecting Forwards. IDS Working Papers 238, Brighton, Sussex BNI 9RE, England.

Coleman, P. T. (2000). Intractable Conflicts. In M. Deutch \& P.T. Coleman (Eds.). The handbook of conflict resolution: Theory and practice. San Francisco: Josse Bass.

Coser, L. A. (1956). The Functions of Social Conflict. London: Routledge / Kegan Paul Limited.

Creswell, J.W. (2009). Research Design: Qualitative, Quantitative and Mixed methods. ( $2^{\text {ndedition}), ~ L o n d o n, ~ S a g e ~ P u b l i c a t i o n s . ~}$

Francis, D. J. (2006). Peace and conflict studies: An African overview of basic concepts. In: G.S. Best (Ed.), Introduction to peace and conflict studies in West Africa: A Reader. Ibadan: Spectrum Books, 15-35.

Galtung, J. (1996). Peace by peaceful means: Peace and conflict, development and civilization (Vol. 14). Sage Publications.

Gentles, S. J., Charles, C., Ploeg, J., \& McKibbon, K. A. (2015). Sampling in qualitative research: Insights from an overview of the methods literature. The qualitative report, 20(11), 1772-1789.

Ghana Statistical Service (2012). 2010 population and housing census. Accra: Statistical Service. http://www.ghanastatiscalservice.com/ populationcensus.htm.

Ghana Statistical Service. (2015). Ghana poverty mapping report. Accessed: www.statsghana.gov.gh on $13^{\text {th March, } 2020 .}$

Israel, G. D. (2003). Determining sample size (Tech. Rep. No. PEOD6. University of Florida, Institute of Food and Agricultural Sciences, Florida.

Kothari C. R., (2004). Research Methodology, Methods and Techniques. New Age International limited. New Delhi. Pg. 95-111.

Kumekpor, T. K. B., (2002). Research Methods and Techniques of Social Research: $\quad$ Accra, Sun Life Publications. 
Longi, F. Y. (2014). The Kusasi-Mamprusi Conflict in Bawku: A Legacy of British Colonial Policy in Northern Ghana. Ghana Studies, 17(1), 157-176.

Nanor, M., Adarkwa, K. K. \& Poku-Boansi, M. (2018). A Measurement of the Determinant of Quality of Life in Kumasi. African Review of Economics and Finance. /ISSN 2042-1478/Volume10.pp; 212-242.

Neuman, W. L. (2014). Basics of social research. Pearson/Allyn and Bacon.

Noagah, B. K. (2013). The peace process in the Bawku conflict in Ghana: Challenges and prospects. Conflict \& Communication, 12(2). URL: www.cco.regener- online.de ISSN 1618-0747.

Olaosebikan, A. J. (2010). Conflicts in Africa: Meaning, Causes, Impact and Solution: $\quad$ An International Multi-Disciplinary Journal, Vol. 4.

PRAAD Tamale, NRG 8/2/214: GKY Syme, "The Kusasi: A Short History" (1932). In Longi, F. Y. (2014). The Kusasi-Mamprusi Conflict in Bawku: A Legacy of British Colonial Policy in Northern Ghana. Ghana Studies, 17(1), 157-176.

Report of the Opoku Afari Commission of Inquiry into the causes of Mamprusi Kusasi Ethnic clashes, December, 1958.

Sandole, D. J. D. (2010). War and Conflict in the Modern World. Peace building: Cambridge, UK: Policy Press, London.

Smith, D. (2004). Trends and causes of armed conflict. In Transforming Ethnopolitical Conflict (pp. 111-127).

Tonah, S., \& Anamzoya, A. S. (2016). Managing chieftaincy and ethnic conflicts in Ghana. Woeli Publishing Services. Also available at www. woelipublishing.com.

Tsikata, D. and Seni, W. (2004). Identities, Inequalities and Conflicts in Ghana. New

Delhi: Sage Publications.

Yin, R., (1984). Case study research: Design and methods (2nd ed.). Beverly Hills, CA: Sage Publishing.

Zartman, I. W. (Ed.). (2000). Traditional Cures for Modern Conflicts: African Conflict" medicine". Lynne Rienner Publishers. 